\title{
PERBANDINGAN DETEKSI PLASMODIUM SPP ANTARA METODE IMMUNOCHROMATOGRAPHIC ASSAY DENGAN METODE POLYMERASE CHAIN REACTION
}

\author{
Johanes Nyoman D. Widiswara Mawan \\ Josef S. B. Tuda \\ Angle M. H. Sorisi \\ Bagian Parasitologi Fakultas Kedokteran Universitas Sam Ratulangi Manado \\ Email: johanesdeomawan@ymail.com
}

\begin{abstract}
Abstrak: Malaria yang disebabkan oleh protozoa dari genus Plasmodium masih menjadi masalah kesehatan di dunia terutama di negara- negara tropis dan subtropis. Kejadian malaria dari World Health Organization (WHO) menunjukan bahwa pada 2010 sebanyak 219 juta kasus menunjukan episode klinik malaria dan 660.000 diantaranya meninggal dunia. Oleh karena itu diperlukan suatu alat diagnosa dini yang memiliki sensitivitas dan spesifisitas yang yang baik. Penelitian ini membandingkan tingkat sensitivitas dan spesifisitas deteksi Plasmodium spp dengan menggunakan metode Immunochromatographic Assay yang biasa dikenal dengan pemeriksaan rapid tes dan Polymerase Chain Reaction (PCR). Penelitian ini merupakan penelitian uji diagnostik dengan sampel sejumlah 30 orang yang diambil secara random sampling pada pasien malaria yang datang ke RSU Budi Mulia sejak bulan September 2013 - November 2013. Sampel adalah spesimen darah yang diambil pada vena brachialis yang sebelumnya telah diberikan inform consent pada pasien dengan gejala trias malaria di daerah Bitung, Manado. Dari sampel darah tersebut dilakukan pemeriksaan dengan PCR. Hasil dari rapid tes dengan metode Immunochromatographic dan PCR dalam mendeteksi Plasmodium spp selanjutnya dilakukan uji diagnostik untuk mengetahui tingkat sensitivitas dan spesifisitasnya. Hasil : Tingkat sensitivitas rapid tes secara umum sebesar $89,2 \%$, spesifisitas sebesar $100 \%$, nilai duga positif sebesar $100 \%$ dan nilai duga negatif sebesar $40 \%$. Simpulan: Nilai sensitivitas yang sedang tetapi memiliki nilai spesifisitas yang tinggi.
\end{abstract}

Kata Kunci : Immunochromatographic Assay, Polymerase Chain Reaction (PCR), rapid tes, sensitivitas, spesifisitas

Abstract: Malaria is caused by protozoa of the genus Plasmodium remains a health problem in the world, especially in tropical countries and subtropical. Incidence of malaria from the World Health Organization (WHO) shows that in 2010 as many as 219 million cases of clinical malaria episodes show and 660,000 of them died. Therefore we need a means of early diagnosis has a sensitivity and specificity are good. This study compared the sensitivity and specificity of detection of Plasmodium spp using Immunochromatographic Assay method commonly known as rapid inspection test and Polymerase Chain Reaction (PCR). This study is a diagnostic test with a sample of 30 people who were taken with random sampling method in malaria patients who come to Budi Mulia Hospital since September 2013 - November 2013. The sample is a blood specimen taken at the brachial vein previously given informed consent in patients with the triad of symptoms of malaria in the area of Bitung, Manado. From the blood samples examined by PCR. The results of the rapid tests and PCR in the detection of Plasmodium spp diagnostic test is then performed to determine the level of sensitivity and specificity. Result: The level of sensitivity of rapid tests in general by $89,2 \%$, specificity of 
$100 \%$, a positive predictive value of $100 \%$ and a negative predictive value of $40 \%$. Conclusions: The sensitivity is moderate but has high specificity.

Keywords : Immunochromatographic Assay, Polymerase Chain Reaction (PCR), rapid tests, sensitivity, specificity

Malaria masih menjadi masalah kesehatan di dunia terutama di negaranegara tropis dan subtropis. Hal tersebut menjadi perhatian utama di dunia kesehatan karena mempengaruhi angka kesakitan bayi, balita dan ibu melahirkan serta dapat menimbulkan kejadian luar biasa. $^{1,2} \mathrm{Di}$ Indonesia dilaporkan pada tahun 2011 mencapai 1.411.156 kasus, dengan jumlah kematian akibat malaria mencapai 1,151 jiwa sedangkan yang belum dikonfirmasi mencapai 935.648 kasus. Jumlah kasus terkonfirmasi per provinsi tahun 2012 khususnya Sulawesi Utara menempati urutan ke-10 dengan jumlah kasus mencapai 5.487, total kasus nasional mencapai 417.816.

Malaria disebabkan oleh protozoa dari genus Plasmodium dan memiliki dua hospes yaitu manusia dan nyamuk. Malaria pada manusia dapat disebabkan oleh Plasmodium falciparum, Plasmodium vivax, Plasmodium ovale, dan Plasmodium malariae. ${ }^{5}$

Pada awal 2010, World Health Organization merekomendasikan untuk semua kasus malaria yang dicurigai harus dikonfirmasi dengan tes diagnostik berbasis parasit, salah satunya adalah rapid diagnostic test ( RDT ) yang merupakan tes cepat untuk mendeteksi Plasmodium dengan metode immunochromatographic assay (ICA). Penggunaan RDT mendukung pengobatan secara universal di daerah dimana pengujian laboratorium tidak tersedia. Tujuan penggunaan RDT ini untuk melakukan deteksi kualitatif cepat Histidine-rich protein 2 (HRP2) oleh $P$. falciparum dan lactate dehydrogenase (pLDH) atau aldolase malaria oleh P.falciparum, P.ovale, P.vivax, P.malariae. ${ }^{2,6}$ Histidine-rich protein 2 (HRP2) merupakan protein yang disintesis oleh Plasmodium dan dilepaskan dari eritrosit yang terinfeksi sebagai protein larut air. Protein tersebut diekskresi oleh eritrosit yang hanya terinfeksi oleh P.falciparum. Lactate dehydrogenase (pLDH) dan aldolase merupakan enzim intraseluler yang mengkatalis reaksi reversibel melibatkan oksidasi laktat menjadi piruvat dengan nikotinamida adenin dinukleotida (NAD) sebagai koenzim. Lactate dehydrogenase (pLDH) dan aldolase dihasilkan oleh semua spesies Plasmodium. ${ }^{2,7}$ Hopkins dan kawankawan $^{8}$ serta Moody ${ }^{9}$ menyebutkan bahwa sensitifitas dan spesifisitas dari RDT dibandingkan pemeriksaan mikroskopik malaria mencapai $\geq 90 \%$.

RDT memiliki beberapa keterbatasan yang dapat mengurangi kemampuannya yakni dalam mendeteksi setting low - transmision: RDT tidak mampu mendeteksi parasitemia lowdensity ( $\leq 120$ parasit/ul), banyak yang kurang sensitif untuk infeksi Plasmodium vivax, dan kemampuannya untuk mendeteksi Plasmodium ovale dan Plasmodium malariae tidak diketahui. ${ }^{10}$ Oleh karena itu, alat alternatif dengan sensitifitas yang lebih tinggi untuk infeksi yang low-density (misalnya tes berbasis asam nukleat) diminta untuk melengkapi diagnostik lapangan yakni dengan Polymerase Chain Reaction (PCR). PCR adalah pemeriksaan biomelekuler dengan cara mendiagnosis parasit berdasarkan asam nukleat menggunakan molekul Deoxyribonucleic acid (DNA) reporter untuk mendeteksi rangkaian DNA atau RNA spesifik yang dimiliki parasit tertentu. ${ }^{11}$

Pada kesempatan ini peneliti ingin mengetahui sejauh mana perbandingan sensitifitas dan spesifisitas deteksi Plasmodium spp antara metode Immunochromatographic Assay (ICA) dengan metode Polymerase Chain Reaction (PCR). 


\section{METODE PENELITIAN}

Penelitian ini merupakan penelitian uji diagnostik dengan populasi penelitian ini adalah pasien malaria yang datang ke RSU Budi Mulia sejak bulan September 2013 - November 2013. Dimana penentuan sampel sejumlah 30 orang dilakukan dengan metode random sampling. Sampel adalah spesimen darah yang diambil pada vena brachialis yang sebelumnya telah diberikan inform consent pada pasien dengan gejala trias malaria di daerah Bitung, Sulawesi Utara. Pengambilan sampel dilakukan oleh petugas kesehatan di rumah sakit RSU Budi Mulia, Bitung. Dari sampel darah tersebut dilakukan pemeriksaan dengan rapid tes dan pemeriksaan PCR di laboratorium Parasitologi FK Universitas Sam Ratulangi Manado. Pemeriksaan rapid tes dengan metode ICA menggunakan kit CareStar $^{\mathrm{TM}}$ Malaria HRP2/pLDH (Pf/PAN) Combo. Sedangkan PCR menggunakan metode Promega. Hasil dari rapid tes dengan dan PCR dalam mendeteksi Plasmodium spp selanjutnya menjadi variabel yang kemudian akan diukur meliputi jumlah true positive (TP), jumlah true negative (TN), jumlah false positive (FP), dan jumlah false negative (FN). TP adalah jumlah sampel yang dideteksi positif dengan pemeriksaan PCR dan digolongkan positif oleh pemeriksaan ICA. TN adalah jumlah sampel yang dideteksi negatif dengan pemeriksaan PCR dan digolongkan negatif oleh pemeriksaan ICA. FP adalah jumlah sampel yang dideteksi negatif dengan pemeriksaan PCR dan digolongkan positif oleh pemeriksaan ICA. FN adalah jumlah sampel yang dideteksi positif dengan pemeriksaan PCR dan digolongkan negatif oleh pemeriksaan ICA. Nilai tersebut kemudian ditabulasi menggunakan Microsoft Exel 2007 dan dilakukan pengolahan data uji diagnostik untuk mengetahui tingkat sensitivitas dan spesifisitasnya menggunakan tabel 2 x 2 . Untuk mendapatkan besar sensitivitas digunakan rumus $\mathrm{TP} /(\mathrm{TP}+\mathrm{FN}) \quad \mathrm{x} 100 \%$, spesifitas dengan rumus $\mathrm{TN} /(\mathrm{TN}+\mathrm{FP})$ $\mathrm{x} 100 \%$, nilai prediktif positif $\mathrm{TP} /(\mathrm{TP}+\mathrm{FP})$ $\mathrm{x} 100 \%$, dan nilai prediktif negatif $\mathrm{TN} /(\mathrm{TN}+\mathrm{FN}) \times 100 \% .^{12}$

\section{HASIL PENELITIAN}

Pada uji diagnostik ini didapatkan hasil sensitivitas, spesifisitas, nilai duga positif dan nilai duga negatif dari sampel darah yang diperiksa menggunakan rapid tes dan PCR yang diperlihatkan pada tabel 1

Tabel 1. Hasil Uji Diagnostik pada Tabel Nilai Prediktif

\begin{tabular}{ccccc}
\hline & & \multicolumn{2}{c}{ PCR } & \multirow{2}{*}{ Total } \\
\cline { 3 - 4 } & & Positif & Negatif & \\
\hline \multirow{2}{*}{ ICA } & Positif & 25 & 0 & 25 \\
\cline { 2 - 5 } & & & & \\
\cline { 2 - 5 } & Negatif & 3 & 2 & 5 \\
\hline \multicolumn{2}{c}{ Total } & 28 & 2 & 30 \\
\hline
\end{tabular}

\section{Sensitifitas}

$\frac{25}{25+3} \quad \times 100 \%=89,2 \%$

\section{Spesifisitas}

$$
\frac{2}{2+0} \quad \times 100 \%=100 \%
$$

\section{Nilai Duga Positif}

$$
\frac{25}{25+0} \quad \times 100 \%=100 \%
$$


Nilai Duga Negatif

$$
\frac{2}{2+3} \quad \times 100 \%=40 \%
$$

\section{BAHASAN}

Rapid tes dalam diagnosa dini penyakit malaria adalah penting, hasil positif dari rapid tes telah di tetapkan sebagai sebagai acuan dalam permulaan pemberian terapi anti malaria yang tidak memiliki laboratorium yang memadai pada daerah berkembang. Di Indonesia sendiri lebih ditekankan untuk mencegah penggunaan anti malaria tanpa mendeteksi adanya plasmodium terlebih dahulu guna mencegah resistensi anti malaria yang meluas serta mencegah resiko komplikasi yang dapat terjadi pada pasien anak-anak dan manula. Saat ini skrining pada pasien dengan gejala trias malaria pada daerah endemik adalah untuk mengetahui secara dini kemungkinan pasien tersebut menderita malaria dengan kecenderungan terjangkit malaria mix. Untuk itulah maka rapid tes dibutuhkan sebagai alat diagnosa dini yang seyogyanya memiliki tingkat sensitivitas dan spesifisitas yang baik agar hasilnya dapat dipercaya dan bermanfaat dalam penggunaannya. ${ }^{10}$

Dari uji diagnostik yang dilakukan terhadap Kit CareStar ${ }^{\mathrm{TM}}$ Malaria HRP2/pLDH (Pf/PAN) Combo yang menggunakan metode ICA didapatkan hasil sensitivitas dalam mendeteksi Plasmodium spp sebesar 89,2\%. Hal ini dikarenakan pada beberapa infeksi mix yakni P.falciparum dan P.vivax yang dideteksi oleh PCR, dari 5 yang terdeteksi hanya 2 sampel yang dideteksi infeksi mix oleh rapid tes dan 3 sisanya hanya terdeteksi infeksi P.vivax, P. ovale atau P.malariae yakni pada sampel nomer 13, 39 dan 40. Faktor yang memungkinkan dapat menyebabkan $P$. falsiparum tidak terdeteksi pada 3 sampel tersebut yakni dikarenakan keterbatasan rapid tes dalam mendeteksi parasitemia low-density $(\leq 120$ parasit/ul). ${ }^{10}$

Dari segi spesifisitas rapid tes menghasilkan angka 100 \% yang berarti kemampuannya sangat baik dalam memastikan bahwa seseorang pasien yang benar-benar tidak terjangkit malaria ketika dilakukan tes dengan rapid tes tidak terdapat Plasmodium spp dalam darahnya. Demikian halnya juga mengenai nilai duga positif yang masing-masing memiliki nilai $100 \%$ dan $40 \%$ yang berarti cukup baik dalam memastikan bahwa seorang pasien sedang terinfeksi Plamodium ssp malaria bila hasil rapid tesnya positif namun sebaliknya jika hasil rapid tes negatif cukup sulit untuk memastikan bahwa pada pasien tersebut tidak terinfeksi Plasmodium ssp.

\section{SIMPULAN}

Tingkat senstivitas dari CareStar $^{\mathrm{TM}}$ Malaria HRP2/pLDH (Pf/PAN) Combo rapid tes yang menggunakan metode ICA terhadap metode PCR dalam mendeteksi Plasmodium ssp di laboratorium Parasitologi Fakultas Kedokteran Universitas Sam Ratulangi sebesar 89,2\%, spesifisitasnya sebesar $100 \%$, nilai duga positif sebesar 100\%, dan nilai duga negatif sebesar $40 \%$.

\section{SARAN}

Dari hasil penelitian uji diagnostik ini diketahui bahwa metode ICA memiliki nilai sensitivitas yang sedang tetapi memiliki nilai spesifisitas yang tinggi. Dan merupakan suatu alat diagnostik yang cukup akurat untuk menjadi suatu alat skrining dalam masyarakat. Pada daerah epidemi malaria maka rapid tes ini dapat digunakan sebagai alternatif dalam penegakkan diagnosis secara cepat dan tepat bagi daerah yang tidak memiliki fasilitas diagnostik yang memadai. 


\section{DAFTAR PUSTAKA}

1. Sutanto I, Ismid Is, Pudji K. S, Saleha $S$, editor. Staf Pengajar FKUI: Parasitologi Kedokteran, Edisi 4. Jakarta. Bagian Parasitologi FKU; 2011

2. Harjianto P N, Nugroho A, Gunawan C A. Malaria dari Molekuler ke Klinis, Ed 2. Jakarta. EGC: 2012

3. WHO. Malaria and its control in the WHO South-East Asia Region. 2012 [Online] [cited 2013 Sept 20]. Available from: http://www.searo.who.int/entity/malari a/topics/Malaria_factsheetWMD2012. pdf

4. Surya A. Malaria: Its Human Impact, Challenges and Control Strategies. Yang dibawakan pada $4^{\text {th }}$ Seminar \& Workshop "Parasitology and Mycology Update: from Laboratory to Clinical Practice” di Manado 12-14 September 2013

5. Agoes R, Natadisastra D. Penyakit oleh Sporozoa Darah dan Jaringan dalam: Agoes R, Natadisastra D, editor. Parasitologi kedokteran: Ditinjau Dari Organ Tubuh yang Diserang. Jakarta. EGC : 2009. Hal: 209-229

6. Chandramohan D, Jaffar S, Greenwood B. Use of clinical algorithms for diagnosing malaria. Trop Med Int Health 2002; 7: 45-52.

7. Marcela E, Evans CB, Taylor W. Identification of Plasmodium falciparum Histidine-Rich Protein 2 in the Plasma of Humans with Malaria. Journal of Clinical Microbiology. 1991, p. 1629-1634

8. Hopkins H, Kambale W, Kamya MR, Staedke SG, Dorsey G, Rosenthal PJ. Comparison of HRP2- and pLDHbased rapid diagnostic tests for malaria with longitudinal follow-up in Kampala, Uganda. Am J Trop Med Hyg [Serial Online] 2007[cited 2013 Oct 20]; 76: 1092-1097. Available from The American Journal of Tropical Medicine and Hygiene

9. Moody A. Rapid diagnostic tests for malaria parasites. Clinic Microbiol Rev 2002; 15: 66-78.

10. Bharti PK, Silawat N, Singh PP et al. The usefulness of a new rapid diagnostic test, the First Response Malaria Combo (pLDH/HRP2) card test, for malaria diagnosis in the forested sbelt of central India. Malar J 2008; 7: 126

11. Coleman et al. Comparisonof PCR and microscopy for the detection of asymptomatic malaria in a Plasmodium falciparum/vivax endemic area in Thailand. Malaria Journal 2006, 5:121

12. Jack W, Carl E. Uji Laboratorium yang Efektif. Ed 1. EGC. Jakarta: 1996

13. McMorrow M. L, Aidoo M, Kachur $P$, malaria rapid diagnostic tests in elimination settings - can they find the last parasite?. Clin Microbiol Infect 2011; 17: 1624-1631 